\title{
DETERMINATION OF STUDENTS' VIEWS ON THE DEVELOPMENT OF TEACHING MATERIAL FROM WASTES
}

DETERMINACIÓN DE LAS OPINIONES DE LOS ESTUDIANTES SOBRE EL DESARROLLO DE MATERIAL DIDÁCTICO A PARTIR DE DESECHOS

\author{
DETERMINAÇÃO DA OPINIÃO DOS ALUNOS SOBRE O DESENVOLVIMENTO DE \\ MATERIAL DIDÁTICO A PARTIR DE RESÍDUOS
}

\author{
Emrah Soykan \\ Near East University - Turkey \\ Erinç Erçă \\ Near East University - Turkey
}

Resumo: Resumo: O objetivo deste estudo é determinar as opiniões de estudantes de educação especial sobre o processo de desenvolvimento de materiais didáticos utilizando resíduos. Esta pesquisa foi realizada com 82 alunos no último ano do curso de graduação do departamento particular de ensino eletrônico. Neste estudo, foram utilizadas como ferramentas de coleta de dados questões de entrevista semiestruturada, compostas por 5 questões. Nesta pesquisa, os alunos desenvolveram materiais para serem usados em atividades de ensino de conceitos no livro didático de conceitos. A pesquisa continuou por 12 semanas no semestre da primavera do ano acadêmico 2018-2019. No final do estudo, observou-se que os professores de pré-serviço usavam garrafas pet como o material usado mais desperdício no processo de desenvolvimento de materiais instrucionais a partir de materiais usados, e formas e texturas eram os assuntos que eles preferiam desenvolver. Com relação à necessidade de desperdício de materiais em termos de profissão docente, os alunos afirmaram que sua conscientização sobre a reciclagem aumentou ao final do processo. Em termos de ganhos no processo, os alunos afirmaram que aprenderam a trabalhar em condições difíceis no final do processo. Como o problema mais comum encontrado no processo de desenvolvimento de materiais com resíduos, os alunos afirmam que os resíduos coletados estão em uma condição muito higiênica.

Palavras-chave: Projeto de material instrucional, resíduos, conscientização ambiental, sustentabilidade.

Abstract: The aim of this study is to determine the opinions of special education students about the process of developing teaching materials using waste materials. This research was carried out with 82 students in the last year of undergraduate program of private e-education teaching 
department. In this study, semi-structured interview questions consisting of 5 questions were used as data collection tool. In this research, students developed materials to be used in activities for teaching concepts in concept teaching book. The research continued for 12 weeks in the spring semester of the 2018-2019 academic year. At the end of the study, it was seen that preservice teachers used pet bottles as the most used waste material in the process of developing instructional materials from waste materials, and shapes and textures were the subjects that they preferred to develop most. Regarding the necessity of waste materials in terms of teaching profession, the students stated that their awareness about recycling increased at the end of the process. In terms of the gains in the process, the students stated that they learned to work in difficult conditions at the end of the process. As the most common problem encountered in the process of material development with waste material, students state that the waste material they collect is in a very hygienic condition.

Keywords: Instructional material design, waste materials, environmental awareness, sustainability.

Resumen: Resumen: El objetivo de este estudio es determinar las opiniones de los estudiantes de educación especial sobre el proceso de desarrollo de materiales de enseñanza utilizando materiales de desecho. Esta investigación se llevó a cabo con 82 estudiantes en el último año del programa de pregrado del departamento privado de enseñanza de educación electrónica. En este estudio, se utilizaron preguntas de entrevista semiestructuradas que constan de 5 preguntas como herramienta de recopilación de datos. En esta investigación, los estudiantes desarrollaron materiales para ser utilizados en actividades de enseñanza de conceptos en el libro de enseñanza de conceptos. La investigación continuó durante 12 semanas en el semestre de primavera del año académico 2018-2019. Al final del estudio, se vio que los maestros de pre-servicio usaban botellas para mascotas como el material de desecho más utilizado en el proceso de desarrollo de materiales de instrucción a partir de materiales de desecho, y las formas y texturas eran los temas que preferían desarrollar más. Con respecto a la necesidad de materiales de desecho en términos de profesión docente, los estudiantes declararon que su conciencia sobre el reciclaje aumentó al final del proceso. En términos de las ganancias en el proceso, los estudiantes declararon que aprendieron a trabajar en condiciones difíciles al final del proceso. Como el problema más común encontrado en el proceso de desarrollo de material con material de desecho, los estudiantes afirman que el material de desecho que recolectan está en condiciones muy higiénicas.

Palabras clave: diseño de material didáctico, materiales de desecho, conciencia ambiental, sostenibilidad.

\section{Introduction}

Human beings, who have been in intense interaction with the environment since their existence, have tried to use nature more in line with their own interests, unlike other living beings, tried to dominate, act selfishly and harm nature more. Environmental waste from human beings constitutes the most important proportion of this damage. In parallel with this, the amount of environmental waste accumulated in nature together with production and 
consumption increases rapidly over time. Recycling is done in order to reduce environmental wastes that cause a great imbalance in nature and these materials are converted to another raw material that can be reused by chemical or physical processes (Büyüksaatçı, Küçükdeniz and Esnaf, 2008). Thus, the environment is cleaned from harmful wastes. At this point, individuals have important duties and responsibilities in recycling waste materials in order not to harm the nature. This can only be done by conscious, sensitive and aware individuals (Karatekin, 2013). When the results of environmental conferences and meetings are examined, it is seen that the main source of environmental problems is human (UÇEK, 2010). However, thanks to the consciousness it possesses, human beings have realized that the harm it causes to nature and the environment they are in will return to itself with the effect of boomerang. After the people's damage to the environment started to be noticed, various studies were carried out in order to raise awareness about the environment and to develop more positive attitudes and behaviors. However, it was determined that individuals do not have the desired level of consciousness in environmental literacy or sub-dimensions (Balkan Kıyıcı, Atabek Yiğit and Selcen Darçın, 2014).

For this reason, it is aimed to integrate the acquisitions in the dimensions of knowledge, attitude, behavior and perception related to the environment to the educational programs prepared with constructivist philosophy, to make individuals become environmental literate individuals, to take a role in solving possible problems, to produce solutions and similar features (MoNE, 2004). In this way, the students who play an important and key role in the future of societies in education and training environments are tried to be made aware of the environment and various activities are organized in this direction (Toto,2019). Developing environmental values, especially in higher education institutions, has become one of the most important issues recently (Kaplowitz and Levine, 2005). Because, students carry the knowledge, skills, attitudes and values related to the environment gained during their university education to their professional, personal life and environment (Teksöz, Şahin and Ertepınar, 2010). In the study of Aydın (2011), it was seen that prospective teachers obtained very efficient results in the development of teaching material from waste materials. It is thought that the activities that will encourage and activate teacher candidates such as material development on research, especially on an important issue concerning all humanity such as waste materials, are considered to have a significant impact on environmental sensitivity. In the development of instructional materials from waste materials, it is thought that, while preservice teachers can see recycling as a method that can save the environment, the activities they use for the use of 
recycling products in their field of study, education are thought to have a significant impact on their environmental sensitivity. In addition to the pedagogical and subject-area competencies of teachers in environmental education, their stance towards sustainability, which has important impacts on role models for students, is one of the hardware components that need attention (Goldman, Ben-Zvi Assaraf and Shaarbani, 2014).

It is very important to ensure that prospective teachers who are educated in faculties of education are qualified about environmental education and problems. It is possible to say that qualified teachers who are qualified about environmental education to be educated have very effective roles in terms of ensuring that future generations can be more sensitive and environmental values individuals. A conscious environmental education will be transferred from generation to generation, especially under the influence of teachers, and a sustainable and livable environment will be opened. It is possible to say that science courses can be more effective in environmental education than other courses in terms of conducting people to understand the interactions in nature. Therefore, science teachers who have the cognitive, affective and psychomotor gains towards today's children who are the owners of tomorrow have great responsibilities. For this reason, in order for environmental education to reach its purpose, first of all science teacher candidates who will provide this education should be sufficient in environment-oriented cognitive, affective and psychomotor fields. The positive attitudes, behaviors and perceptions of the preservice teachers towards the environment are very important in terms of their future professional equipment. It is possible to say that pre-service teachers 'environmental attitudes, behaviors and perceptions levels can positively affect the students' assessment of the environment. In some researches, it has been determined that the lessons carried out by the activities and activities in which the students are active in teaching environmental issues positively affect the students' assessment of environmental issues (Balkan Kıyıcı et al., 2014; Akkurt, 2007). The use of instructional materials prepared in accordance with the principles of instructional technology is of great importance for individuals to acquire these characteristics (Şahin \& Yıldırım, 1999, p. 1).Preparing effective learning environments in schools is among the duties of teachers. Teachers prepare the materials themselves or use the ready materials in line with the subject, aims and achievements of the lesson, attracting the interest of the students in the learning-teaching process, increasing academic success and contributing to the permanent learning. According to the studies conducted in this context (Kablan and Topan, 2013; Öztürk, 2012), it is seen that when the materials prepared are used in the courses, they provide active learning, support individual learning, change the students' 
point of view positively and have a positive effect on academic achievement. Students working in the school environment and presenting the materials they prepare in the course increase the responsibilities and motivation of the students in preparing materials. Reception (2013) Instructional Technology and Material Design course is a course that informs prospective teachers about developments in instructional technologies, and also provides opportunities and opportunities for prospective teachers in preparing and using materials. The author (2015) states that in order to make the maximum use of the ÖTMT course, prospective teachers should activate the student through student-centered instruction increase the effectiveness of practices and keep up-to-date tools and materials in the classrooms. Within the scope of this study, within the scope of Instructional Technologies and Material Design Course in the last year of special education teachers, it is aimed that students develop instructional materials for their chosen subjects. In this study, student-centered teaching has been adopted and the teachers of special education teaching department have been actively involved in the center of learning and have been provided to develop instructional materials and instructional materials from waste materials for instructional technologies and material design courses. The waste materials used in this process, the evaluation of the use of waste materials in the development of materials in terms of teaching profession and the opinions of prospective teachers towards the environment were examined.

At the end of the research, the following questions were answered:

1- What are the waste materials you use for material development?

2- What kind of materials and for which purposes did you develop these materials?

3- What do you think about the necessity of waste material use in teacher profession in material design course?

4- What are your views on the benefits of waste material use in the material design course, and what did it add to you?

5- What are the problems you faced in the process of designing materials using waste materials in Material design course?

\section{Methodology}

In the study, which was designed according to qualitative research model, easily accessible situation sampling, one of the purposeful sampling methods, was used in sample selection. 


\section{Participants}

The research was conducted with the students of a faculty of education at a private university in the spring semester of 2018-2019. A total of 82 students in the fourth year of the undergraduate program of special education teachers participated in the study. 52 of the students participated in the study were male and 28 of them were female students.

\section{Data Collections and Analysis}

For the purpose of this study, in order to collect the data, a personal information form prepared by the researchers and a review of the relevant literature were prepared and an interview form consisting of six open-ended questions that determined the pre-service teachers' thoughts and knowledge levels for the development of the teaching materials from waste materials was prepared. 6 lecturers working in the fields of Special Education, CEIT and Environmental education were consulted and interview questions were arranged. Then, a pilot study was conducted with four prospective teachers to determine the final version of the interview questions. In the analysis of the collected data, content analysis method was used. Content analysis is the process of compiling and interpreting similar data in a comprehensible way by bringing together certain concepts and themes (Yıldırım \& Şimşek, 2013). The content analysis of the interviews was conducted separately by the researchers. Then, the researchers compared the themes they created and the content of the themes. The agreement percentage of the themes was $75 \%$ and the agreement content of the themes was $83 \%$. The reliability of the study was determined using Miles and Huberman (1994), Percent Compatibility Formula [P = $(\mathrm{Na} / \mathrm{Na}+\mathrm{Nd}) \times$ 100] (P: Percent Compatibility, Na: Compliance Amount, Nd: Conflict Amount). When the percentage of agreement in the reliability calculation is $70 \%$, it is accepted that the reliability percentage has been reached (Yıldırım \& Şimşek, 2013).

\section{Research Process}

In this research, students developed materials to be used for teaching purposes in order to gain concepts on many different subjects consisting of waste materials for 12 weeks. They used the principles of material preparation indicated by Yanpar (2007) in designing and 
developing instructional materials. Pre-service teachers designed materials for many different concept subjects (color, number, size, smallness, scarcity, plurality, story map) and used only waste material when developing materials. For example, they developed interactive materials using waste cardboard boxes and bottle caps to teach spelling. Teacher candidates made the materials individually. Each student developed a material using waste materials. Teaching materials developed using waste materials were developed under the supervision of the instructor within the scope of instructional technologies and material development course. Before starting the development process, the students were informed that they could use all the materials that they thought would be useful in the course of material development process and the students determined which waste materials they would make their materials.

\section{Results and discussion}

Within the context of the study, a total of 82 students were interviewed. Of the interviewers, 28 are females and 52 are males. Of the interviewees, 42 are in the age group 21 years old, 21 are in the age group 23 years old and 19 are in the age group 24years old. All of the interviewees are from special education department.

\section{What are the waste materials you use for material development:}

The coding and tabulation process of the descriptive analysis on the data obtained as a result of the students' views on waste materials used for material development is given in table 1. The students identified multiple waste materials.

Table 1: What are the waste materials you use for material development.

\begin{tabular}{|l|l|}
\hline Views & f \\
\hline Bottle & 68 \\
\hline Ice Cream Sticks & 56 \\
\hline Bottle Caps & 54 \\
\hline Cardboard Boxes & 48 \\
\hline Detergent Packaging & 45 \\
\hline Deodorant Box & 41 \\
\hline Old Newspaper & 29 \\
\hline Smoking Packages & 28 \\
\hline Egg Packaging & 26 \\
\hline Yogurt Container & 25 \\
\hline Cone & 25 \\
\hline
\end{tabular}




\begin{tabular}{|l|l|}
\hline Used Battery & 23 \\
\hline CD & 19 \\
\hline Bag & 18 \\
\hline Ceramic Fittings & 15 \\
\hline Small Dry Tree Branches & 12 \\
\hline My Unused Clothes & 9 \\
\hline Toothpick & 8 \\
\hline Pipette & 7 \\
\hline Surrounding Wood Pieces & 6 \\
\hline
\end{tabular}

As can be seen in Table 1, it was seen that students used pet bottles as the most commonly used waste material in the material development process. Then, other waste materials preferred by the students are ice cream sticks, bottle caps, cardboard boxes and detergent boxes.

Some students' views on these statements are as follows;

S.V.1: "When my teacher first announced that we would develop material from waste materials, I immediately thought about pet bottles. So I thought about using pet bottles. I already had a lot of bottles at home, and I was thinking about what to do with them, and it worked very well in this class."

S.V.2: "While I was walking around, Inoticed my wooden ice cream sticks on the floor and I thought I could use them to develop materials. Then I realized that there was so much around that it made me produce really good things.

S.V.3: "As soon as we left the class, we all noticed the same thing as we went to the cafeteria with friends. We've seen a lot of covers in the corner on the shore, and we thought it would work, and so it happened. "

\section{What kind of materials did you develop with these waste materials and for what purposes:}

The coding and tabulation process of the descriptive analysis on the data obtained as a result of the students' views on the question of what kind of materials and for which purposes did you develop materials are given in Table 2 .

Table 2: Material types and subjects developed by students.

\begin{tabular}{|l|l|}
\hline Views & f \\
\hline Shapes and Textures & 22 \\
\hline Animals Subject & 12 \\
\hline
\end{tabular}




\begin{tabular}{|l|l|}
\hline Musical instruments & 12 \\
\hline Big-Small Concept & 11 \\
\hline Color Teaching & 10 \\
\hline Addition and substraction & 10 \\
\hline Puppet Making & 8 \\
\hline Sense organs & 7 \\
\hline Teaching Spelling & 7 \\
\hline Teaching Motor Skills & 5 \\
\hline Dirty Clean Concept & 4 \\
\hline Hand-Eye Coordination Development & 4 \\
\hline
\end{tabular}

As it is seen in Table 2, the most preferred topics for the materials that the students developed using waste materials are; shapes and textures, animals, musical instruments, big and small concept, color teaching and addition and subtraction process.

Some students' views on these statements are as follows;

S.V.1:"While thinking about what I can teach with the waste materials I found, the patterns and textures on it caught my attention. Each of them, for example, wood, nylon, paper, plastic, glass texture is different. I planned to use it for motor development by transforming it into a teaching process."

S.V.2:"By combining all of the cones I found with the other wastes I found, I managed to make them look like different animals with small touches, and very nice materials came out, I didn't even expect. For example, I used it to teach many animals such as penguins, birds, rabbits and chickens."

S.V.3:“Great musical instruments have emerged especially from pet bottles and glass bottles. The sand and stone pieces we put in and the wood pieces produced very different sounds"

\section{What do you think about the necessity of the use of waste materials for material design in teacher profession?}

The coding and tabulation process of the descriptive analysis on the data obtained as a result of the students' views on the question of what kind of waste materials and for what purposes did you develop materials are given in Table 3 . 
Table 3: Students' views on the necessity of the use of waste materials for designing materials in the teacher profession.

\begin{tabular}{|l|l|}
\hline Views & f \\
\hline I will benefit a lot in my future career & 80 \\
\hline My Recycling Awareness Raised & 79 \\
\hline $\begin{array}{l}\text { Our discovery of waste materials positively reflected our material development process } \\
\text { academically }\end{array}$ & 74 \\
\hline Providing economy in supplying materials & 62 \\
\hline We realized how we could develop materials in difficult conditions & 59 \\
\hline Developed my imagination & 57 \\
\hline I started to think about how to transform everything I see around me. & 48 \\
\hline Creative pushed to think & 45 \\
\hline
\end{tabular}

As can be seen in Table 3, the data obtained from the students' opinions about the necessity of the use of waste materials for the purpose of designing materials; At the end of the process, students stated that they will benefit from these wastes and issues in their future professional lives. In addition, it is seen that recycling awareness among students increased positively. As another important result, the students stated that finding waste materials on their own contributed to the process more effectively while developing the material. In addition, as an effective result, students stated that they could develop materials in a much more economical way.

Some students' views on these statements are as follows;

S.V.1: "After studying this lesson in this way and collecting many different waste materials from the environment, I realized that my sensitivity towards each waste material increased and I wanted to take them and produce something."

S.V.2: "With the guidance of our teacher, searching for and finding waste materials motivated me more against the lesson and against a product that I would produce myself. I realized in previous lessons that we were more passive and did not actively participate. "

S.V.3: "I took the first course in the last semester. In order to improve the materials, we had to constantly buy materials. Some of our friends could not develop good material because they could not get enough material due to financial means. But with this application, we have developed much better than the materials we actually make and the materials we buy." 


\section{What are your views on the benefits of using waste materials in the material design course?}

The coding and tabulation process of the descriptive analysis on the data obtained as a result of the students' views on the gains of waste material use in the material design course is given in Table 4.

Table 4: Students' views on the benefits of waste materials in material design course.

\begin{tabular}{|l|l|}
\hline Views & f \\
\hline I learned to work in difficult conditions & 68 \\
\hline I realized how much waste we throw into the environment & 58 \\
\hline Increased my sensitivity to the environment & 45 \\
\hline Improved my problem-solving skills & 43 \\
\hline Our creativity has improved & 39 \\
\hline I learned to evaluate my old things in the house & 37 \\
\hline Taught me to be thrifty & 31 \\
\hline
\end{tabular}

As can be seen in Table 4, the data obtained from the students' opinions about the gains of waste material use in material design course; students stated that there was positive progress in working under difficult conditions at the end of this period. As a result, students stated that they realized how much waste was left in the process of collecting the waste materials they needed. Later, they stated that their sensitivity to the environment increased. Some students think that creating something from scratch with their raw material also contributes to problem solving.

Some students' views on these statements are as follows;

S.V.1: "After I started the process, I imagined that I was working in a school where financial resources were poor and I really realized how much it would work to make all these materials with waste materials. Because sometimes the facilities of the school are inadequate;

S.V.2: "We started collecting waste materials to improve our materials and we could easily find them. Then we realized with friends how much waste we throw around. It was easy to find stuff because there were so many around. I think that was one of the points our teacher wanted to show us, I believe we got the message." 
S.V.3: "After the process, we completed our materials. What changed the most was that I started to notice people walking around on the road and thinking about what I could do against them. I've taken it upon myself, and I think my awareness has increased tremendously."

\section{What are the problems encountered in the process of material development using waste materials}

The coding and tabulation process of the descriptive analysis on the data obtained as a result of the students' views on the problems encountered in the material development process using waste materials is given in Table 5.

Table 5: Students' views on the problems encountered in the process of designing materials using waste materials in material design course.

\begin{tabular}{|l|l|}
\hline Views & f \\
\hline We need to clean hygienically & 76 \\
\hline Sometimes it doesn't come out with the strength we want & 71 \\
\hline $\begin{array}{l}\text { Sometimes it was difficult for the same substance to find a similar } \\
\text { one }\end{array}$ & 65 \\
\hline We are trying hard to put waste materials into the form we want & 56 \\
\hline $\begin{array}{l}\text { Sometimes it was difficult to decide which material to use for which } \\
\text { topic }\end{array}$ & 45 \\
\hline $\begin{array}{l}\text { Since I'm used to ready-made materials, I had a hard time producing } \\
\text { scratches and wastes from scratch. }\end{array}$ & 34 \\
\hline It is weaker than the materials we purchase as durability & 26 \\
\hline
\end{tabular}

As can be seen in Table 5, the data obtained as a result of the students' views on the problems they face during the material design process using waste materials in the material design course; students stated that the materials they found in this process are not hygienic and they should clean them before starting the study and this prolongs the process. As another point of view, they stated that the waste materials obtained from the environment are not sufficiently robust to be used as material and that they cannot be used for a long time in terms of durability. Another striking result is that students often find it difficult to provide the same type of waste materials that they find for use in the material development process. In this case, they stated that it prolonged the process again. 
Some students' views on these statements are as follows;

S.V.1: "I had to clean thoroughly the detergent containers, cardboard boxes, empty beverage packaging I found in the markets before using them. This extended the process."

S.V.2: "It was the most negative event I had during the whole process. After collecting the ice cream sticks, I started to improve my material, and a few of them were broken when it was almost finished. I think I think they're deformed because they've been out there a long time. All I did was end up wasted, and then I had to do it again. After checking the other items I found, I started working. "

S.V.3: "I think the biggest problem I encountered was to find another mate of the same substance. Because I had to use more than one same item for some of the topics I chose, but it was hard to find the same item as each other, I remember looking for quite a bit."

In conclusion, when the content analysis data obtained from qualitative analysis were examined, it was seen that the students who participated in the research stated that the process of producing course material for the course of material development from waste materials positively affected them. When the students who participated in the study examined the statements, it was found that they used pet bottles, ice cream sticks and pet bottle caps as the most used waste materials in the process. Aydın (2011) also pointed out the use of plastic wastes in recycling and material making. Taner (2007) also developed teaching materials from plastic wastes and emphasized in his study results that he obtained effective results. It was found out that the students developed teaching materials about the waste materials that they collected in the process and Shapes and Tissues Animals Subject Musical Instruments. It is important to note that the students participating in the research emphasize the concept of recycling, which plays a very important and key role in the balance of nature, and that they are now more sensitive and responsible in this regard. Benzer (2010) stated in his study that such nonenvironmental activities were positively reflected on students' environmental awareness. The results of the content analysis showed that a significant part of the participants stated that the process of developing teaching materials and waste materials for twelve weeks would make a significant contribution to the teaching profession in later life. Çapar (2008) concluded that working with three-dimensional materials contributed positively to the teaching process. Looking at the findings of the students' gains at the end of this process, the students stated that they learned to produce something from scratch with the waste materials they found in the environment without qualified materials under difficult conditions. When we look at another finding that emerged during this process, they stated that while reaching the waste materials 
collected by the students, they realized how unconsciously these wastes were discharged to the environment by the people and how much this ratio was. As another point, the research findings show that the biggest problem they face in this process is that when they find waste materials, they cannot be used hygienically and they spend time to clean. Another important point emphasized on this issue is that students deform the waste materials they collect from the environment in the process, making the process difficult.

\section{REFERENCES}

1. Alım, M. (2013). Acquisitions of Prospective Geography Teachers in The Instructional Technology and Material Design/Development Course. Eastern Geographical Review, 20(33):1-10.

2. Aslan, A. (2015) Design and Effectiveness of Interactive Out-of-Class Chemistry Environment, PhD Thesis, Karadeniz Teknik Üniversitesi, Trabzon.

3. Avan Ç., (2011). Determination of Student Attitudes on Recycling and Environmental Effects of Plastic and Plastic Wastes, Msc. Thesis, Kastamonu University, Kastamonu, Turkey.

4. Aydin, A. (2011). The development materials from substances waste for some topics in science and technology textbook for primary. Necatibey Eğitim Fakültesi Elektronik Fen ve Matematik Ĕgitimi Dergisi (EFMED), 5(1): 62-93.

5. Balkan Kıyıcı, F., Atabek Yiğit, E.,Selcen Darçın, E. (2014). Investigation of PreService Teacher's Opinion and Environmental Literacy Level Change with Nature Education. Trakya Journal of Education, 4(1): 17-27.

6. Benzer E. (2010). The Effect of Environmental Education Course Prepared by Project Based Learning Approach on Environmental Literacy of Science Teacher Candidates. $\mathrm{PhD}$ University, İstanbul.

Thesis, Marmara

7. Büyüksaatçı, S., Küçükdeniz, T., Esnaf, Ş. (2008). Geri dönüşüm tesislerinin yerinin gustafson-kessel algoritmas1-konveks programlama melez modeli tabanlı simülasyon ile belirlenmesi. Istanbul Ticaret Üniversitesi Fen Bilimleri Dergisi, 7 (13): 1-20.

8. Çapar, M. (2008). İlköğretim ikinci kademe görsel sanatlar eğitimi dersinde üç boyutlu çalışmaların önemi. Çukurova Üniversitesi Ĕgitim Fakültesi Dergisi, 3(4): 114-124. 17

9. Efe H.A. \& Baran, M. (2017). The Effects of Process of Developing Instructional Materials on Pre-Service Teachers' Environmental Attitudes, Behaviors and Perceptions, YYU Journal Of Education Faculty, 14(1): 22-46. DOI: 10.23891/yyuni.2017.1

10. Goldman, D., Yavetz B.,Pe'er, S. (2014). Student teachers' attainment of environmental literacy in relation to their disciplinary major during undergraduate studies. International Journal of Environmental \& Science Education, 9(4): 369-383. DOI: $10.12973 / \mathrm{ijese} .2014 .22 \mathrm{a}$

11. Kablan, Z. ve Topan, B. (2013). The Effectiveness Level of Material Use in Classroom Instruction: A Meta-analysis Study. Educational Sciences: Theory \& Practice, 13(3): 1629-1644. DOI:10.12738/estp.2013.3.1692

12. Kaplowitz M. D.,Levine R. (2005). How environmental knowledge measures up at a Big Ten university. Environmental Education Research, 11(2): 143-160. https://doi.org/10.1080/1350462042000338324 
13. Karatekin, K. (2013). Developing a scale to measure pre-service teachers' attitudes towards solid waste and recycling: a validity and reliability study. International Journal of Eurasia Social Sciences, 10:71-90.

14. Öztürk, İ.H. (2012). Design-based learning approach for developing ict-based teaching skills of history student-teachers. E-Journal of New World Sciences Acedemy, 7(3):945-968.

15. Teksöz, G., Şahin E., Ertepınar, H. (2010). Environmental literacy, pre-service teachers, and a sustainable future. Hacettepe Üniversitesi Ĕ̈itim Fakültesi Dergisi, 39: 307-320.

16. Taner, M.S. (2007). Plastik ve bilinen en kansorejen madde dioksin. Doğa ve Çevreyi Koruma Derneği. Available online: http://dogader.org/index.php/bilgi/80plastik-ve-bilinen-en-kanserojen-madde-dioksin

17. Toto, G. A. (2019). Effects and Consequences of Media Technology on Learning and Innovative Educational Strategies. Online Journal of Communication and Media Technologies, 9(1): e201902. https://doi.org/10.29333/ojcmt/3988

18. Yazar, T. (2015). Pre-service teachers' views on instructional technologies and material design course. Uluslararası Ĕgitim Programları ve Öğretim Çalışmaları Dergisi, (5) 9: 23-34.

\section{SOBRE OS AUTORES:}

\section{Emrah Soykan}

Near East University, Faculty of Education North Cyprus 99100. Turkey

E-mail: emrah.soykan@ neu.edu.tr

(iD http://orcid.org/0000-0002-0385-1404

\section{Erinç Erçăg}

Near East University, Faculty of Education North Cyprus 99100. Turkey

E-mail: erinc.ercag@neu.edu.tr

(iD) http://orcid.org/0000-0002-7830-1722

Recebido em: 24 de outubro de 2019 